\title{
Chinese-foreign Cooperation in Running Private Colleges and Universities: Possibility and Problems
}

\author{
Du Shixiong \\ Qi Fang Education Research Institute, Xi’an International University, Xi’an, Shaanxi, 710077
}

Keywords: private colleges and universities; Chinese-foreign cooperation in running schools; experience; First-class

\begin{abstract}
Internationalization is the future trend of the development of private colleges and universities, and Chinese-foreign cooperation in running schools is an important way to internationalize private colleges and universities. This paper takes the cooperation between Chinese private colleges and universities and foreign schools under the background of Chinese-foreign cooperation in running schools, and put forwards the current problems which could provide some inspirations and deliberations to the private colleges and universities after investigating the successful samples of Chinese-foreign cooperation in running schools; this paper focuses on the analysis of the problems of the private colleges and universities at present, and puts forward the countermeasures for changing old conception, people-centered, and taking the cultivation of outstanding talents as the goal of private colleges and universities; at the same time, private colleges and universities must persist in the premise of keeping the public welfare of education, in this way, they can break through the set pattern of the profitability of education; and then, private colleges and universities can begin making profit healthily. The specific methods are drawing support form the government, constructing the first-class team of teachers, majors, and disciplines, so as to lay a solid foundation for "introducing foreign high-quality education resources".
\end{abstract}

Chinese-foreign cooperative colleges and universities, the public schools, and the private schools are esteemed as the "Three Powerful Impetus" of the higher education of China ${ }^{[1]}$. According to the information from the official platform of China Ministry of Education for supervising Chinese-foreign cooperation in running schools, by October of 2017, 2,572 Chinese-foreign cooperative projects have been established or run with the administrative authorization, and these projects spread over 28 provinces (municipalities) throughout China ${ }^{[2]}$. However, only 60 private colleges and universities (most of them are independent colleges) participate in setting up or organizing the cooperation institutions or projects which number is 120 , accounting for $5 \%$. This is far away from the position and status of the private colleges and universities which are "an important force in promoting the reform of education"; and this is also not fit for the brilliant achievements that the private colleges and universities, which are the "important component of socialist education cause", have made in the field of higher education.

\section{Present Situation and Problems in the Development of Chinese-foreign Cooperation in Running Schools}

The development of Chinese-foreign cooperation in China is growing with the process of the Reform and Opening-up. In keeping with the rapid development of the economy at that time, China put a series of policies for promoting Chinese-foreign cooperation in running schools into force one after another, especially the Regulations of Chinese-foreign Cooperation in running Schools in 2003 and the Measures for Implementation of Regulations of Chinese-foreign Cooperation in running Schools in 2004 had provided the detailed laws and policies on Chinese-foreign cooperation in running schools to the public, so that the Chinese-foreign cooperation in running schools had been pushed to a climax. Since then, Chinese-foreign cooperation in running schools has gradually become a prairie fire in China. However, from the aspects of cooperative colleges, regional distribution, levels of these schools, quality and supervision and so on, there are still many 
problems that need to be improved. For example, in terms of regional distribution, Chinese-foreign cooperative schools are mainly concentrated in the provinces (municipalities) such as Beijing, Shanghai, Jiangsu, Zhejiang, Guangdong and Heilongjiang, etc. The vast central and western regions have few relevant institutions or cooperative schools. As a province with advanced private higher education, Shaanxi is far away from excellent on introducing foreign high-quality education resources into China; although the amount of financial support from the government for the private colleges and university is 400 million a year, but these schools still do not do well in running schools by means of international cooperation. Moreover, most of the cooperative programs belong to the " 985 " or the " 211 " universities or their independent colleges. Under this background, how the private colleges and universities to take part in the Chinese-foreign cooperation in running schools? And which is best method, to create conditions, to go upstream undauntedly, to conform to the trend, or to maintain the status quo, to become bigger and stronger, and to make a comeback?

\section{Successful Samples of Chinese-foreign Cooperation in Running Schools and the Inspiration}

After 40 years rapid development of Chinese-foreign cooperative education, some sample schools have emerged. SHU-UTS SILC Business School, Shanghai University, based on the changes of key points of the cooperation between Chinese and foreign university, has actualized the sustainable development of Chinese-foreign cooperation in running schools by means of introducing the project, imitating and assimilating the project; by means of building the teams of teaching, setting up good majors, constant development of scientific research, system innovation, education output, etc, the colleges and universities own their core-competitiveness step by step ${ }^{[3]}$. University of Nottingham Ningbo China is different from other models of "single introduction" and "partial introduction" of Chinese-foreign cooperation in running a school, instead, it not only is people-oriented; but also pursues the combination of high level cooperation and the public welfare, and introduces foreign high-quality education resources as a whole ${ }^{[4]}$. The cooperative project, which is demand-oriented, between Xi'an Jiaotong University and Hong Kong Polytechnic University bases on the reality of the development of Shaanxi Province and the western regions; it is excellent in selecting quality education resources, selecting students and selecting teachers in accordance with the first-class standards of international education; it follows the principles of project management in the cooperation; at the some time, it emphasizes innovation and training abilities of the participators. What's more, it actively explores the new mechanism of the Chinese-foreign cooperation in running colleges and universities of western China. There are two obvious features in Chinese-foreign cooperative education. One is the guiding ideology that introducing foreign high-quality education resources is very clear; the other is the trend of introducing applied education instead of academic education.

Of course, as a new thing, there are many deficiencies in Chinese-foreign cooperation in running schools. First, the quality of students is weak. Excepting some schools that have legal personality can recruit the new students whose admission score reaches the standard of domestic key universities in their Chinese-foreign cooperative projects, but many schools' score requirement is very low, and even some of them do not have to hold a matriculation. Second, the majors of these projects are few. In these projects, the majors mainly focus on management, accounting, computer, and information technology, etc; many projects set the some major, so that the majors of the cooperative project are few. Moreover, seen from the foreign countries, most the foreign countries are those countries which take overseas education as an industry for incomes, such as the USA, the UK, and Australia, etc ${ }^{[5]}$. Third, the infrastructures and teaching staff of Chinese-foreign cooperative colleges need to be improved. According to the relevant laws and regulations such as opinions of the Ministry of Education on some problems of Chinese-foreign Cooperation in running Schools, the four "1/3" principle, which requires some necessary requirements in running cooperative colleges, should be strictly obeyed. But in fact, many Chinese-foreign cooperative colleges and universities in China can not meet the requirements except few schools; many schools are not qualified. In the end, the lack of regulatory mechanism is also one of the reasons for the criticism of the Chinese-foreign cooperative schools from the public. 


\section{Discussion on the Causes of Slow Development of Chinese-foreign Cooperation in Running Private Colleges and Universities}

Problems that exist in public colleges and universities in Chinese-foreign cooperation in running Schools also exist in private schools. But because of the different system and property, the private colleges and universities has the different features of their own.

First, it is one of the reasons for the slow development of private colleges and universities----there are few laws and policies in accordance with the developmental characteristics of the private higher education. For example, Xue Weiyang ${ }^{[6]}$ believes that the main reason for the weak development of Chinese-foreign cooperative education in private colleges and universities is the lagging of relevant laws, regulations and policies. In particular, the contradiction between the essence of investment in running a school by private universities in China and the prohibition of profit-making in Chinese-foreign cooperative education is the main reason for the weak development of Chinese-foreign cooperation in running private colleges and universities, and Wang Shurong ${ }^{[7]}$, Chen $\mathrm{Li}^{[8]}$ hold the some opinion. What's more, weak actual strength in running schools of the private colleges and universities is also a fatal influencing factor. The shortage of financial investment is one problem that has been bothering the private colleges and universities; moreover, the lack of excellent teachers and the majors which aim for training the practical students in a short term are also the factors that influencing the further development of the schools; at the some time, the weak understanding of the leaders to the present situation, the ossification of the cooperative system, and the non-standard management, these also blocked the development of Chinese-foreign cooperation in running private colleges and universities ${ }^{[9]}$.

Chinese-foreign cooperation in running schools is also a public welfare cause. The new Private Education Promotion Laws has strengthened the support for the development of private colleges and universities after carrying out the classified management. Secondly, internationalization is the pursuit of private colleges and universities, and Chinese-foreign cooperation in running schools is an important way to improve the quality of private higher education. The real reason for the slow development of Chinese-foreign cooperation in running schools is the weak actual strength of the private schools; among them, the team building of the staff is the most important factor.

\section{Suggestions on Promoting the Development of Chinese-foreign Cooperation in Running Private Colleges and Universities}

The shortage of financial support is always one of the key factors that blocks the rapid development of the private colleges and universities with high quality, the new Private Education Promotion Law and the relevant policies all provide strong supports to the schools. Therefore, In such a good situation, private colleges and universities must seize the opportunity, take advantage of the opportunity of "the Belt and Road" strategy, work in a down-to-earth manner, engage in unostentatious hard work, improve the teaching quality, so as to broaden the ways of accelerating the development of private colleges and universities and lay a solid foundation for the Chinese-foreign cooperation in running private schools in the new times.

School is the place where cultivates, improves and perfects the students, so the education cause has the feature of public welfare. The goal of Chinese-foreign cooperation in running schools is to introduce the overseas excellent teaching resources into China, so as to improve the teaching quality of China. Only the owners of the private colleges put the public welfare in the first place, and pursue the ultimate goal of constructing the schools as a "century-old school", could the schools develop healthily.

Highlighting the team building of the teachers, making the famous majors, disciplines by improve the quality of the teachers, so as to lay a solid foundation for the Chinese-foreign cooperation in running private colleges and universities.

The excellent team of teachers not only means excellent teaching quality, but also means the healthy further development of the school. No matter how many main functions the higher education has, but all the functions can not work without human. Therefore, to cultivate and build 
the strong team of teachers is the necessary way to promote the development of the Chinese-foreign cooperation in running private schools.

Striving for the official supports under the background of carrying out the new Private Education Promotion Law, so as to get to more favorable financial support for Chinese-foreign cooperation in running private colleges and universities.

After the new Private Education Promotion Law was put into force, the government has provided many strong supports for the development of private colleges and universities in many aspects. The problem that has bothered the private colleges and universities for many years----funds shortage---has been greatly improved to some extent. Under this background, if the private colleges and universities could follow this trend, and increase the investment in disciplines, majors and teacher's cultivation, it is believed that the flexible management mechanism of private colleges and universities will certainly create their own characteristics, own brand and own competitive power; only the private schools have this kind of characteristics, reputation, and power can the schools actualize the goal of Chinese-foreign cooperation----to introduce the excellent teaching resources into China.

\section{Conclusion}

Chinese-foreign cooperation in running schools is the inevitable trend of internationalization of higher education. Colleges and Universities was founded by the cooperation between China and foreign countries, public colleges and universities, and that of private have become the "Three Powerful Impetus" of the higher education in China. But at present, Chinese-foreign cooperative education mainly means to the cooperation between public universities and foreign countries, and the projects are mainly aims for training applied talents, and the projects has the trend of setting the some majors in different schools and questing for profit excessively, which is contrary to the essence of the public welfare of education. Because of its own problems, private colleges and universities are in the disadvantageous position in the Chinese-foreign cooperation in running schools. Only the domestic private colleges and universities improve their teaching quality could they promote the development of their cooperation with the foreign colleges and universities. By means of the strong support of the new Private Education Promotion Law, the private colleges and universities must change the old idea, take the person as the centre, and take the cultivation of talents as their pursuits, so as to construct the first-class team of teachers, majors and subjects.

\section{Acknowledgements}

Pro: Scientific Research Program Funded by Shaanxi, Provincial Education Department (Program No. 16JZ059)

\section{References}

[1] Liu Mengjin. On the Identification of the Chinese and Foreign Cooperative Universities is Public or Private [J]. China Higher Education Research, 2014(11):81-84.

[2] Lin Jinhui. The New Features, New Issues, and New Trend of Chinese-foreign Cooperation in Running Schools in the New Times[J]. China Higher Education Research, 2017(12):35-37+55.

[3] Gong Siyi, Lv Kangjuan. On the Construction of the Core Competitive Power of the Institutions of Running Schools by Chinese-foreign Cooperation----Taking a University for Example[J]. Journal of National Academy of Education Administration, 2017(2): 28-33.

[4] Hua Changhui, Xu Yafen, Shen Weiqi, etc. Try Our Best to Construct a Successful Model of Running School by Chinese-foreign Cooperation----Exploring the Special School running model of University of Nottingham Ningbo China Once More[J]. China Higher Education Research, 2010(23):15-18. 
[5] Xiang Xin, Hou Hairong, Tang Nan. The Chinese-foreign Cooperation in Running Schools of Jilin Province----Current Situation, Problems, and the Countermeasures[J]. Modern Education Science, 2017(02): 19-27.

[6] Xue Weiyang. The Present Situation, Predicament and Breakthrough of the Development of Chinese-foreign Cooperation in Running Schools by Private Colleges and Universities[J]. Fudan Education Forum, 2016, 14(03): 46-52+59.

[7] Wang Shurong, Ji Guoming. Chinese-foreign Cooperation in running Private Colleges and Universities: Obstacles and Countermeasures[J]. Border Economy and Culture, 2011(10):79-81.

[8] Chen Li. Main Problems and the Suggestions on Developing Chinese-foreign Cooperation in Running Private Colleges and Universities[J]. Journal of Huanghe S\&T University, 2011,13(05): $14-17$.

[9] Wang Jun, Wang Bingbing. The Present Situation and Some Problems in the Development of Chinese-foreign Cooperation in running Private Colleges and Universities[J]. Wenjiao Ziliao, 2017, (24).

\section{About the Author:}

Du Shixiong (1969-), male, comes form Baoji, Shaanxi Province.

Titles: Editor; Researcher of Research Centre for Private Education in Xi'an International University

Research Direction: Private higher education 